Maria Conterno

\title{
Shaping the Good Christian King under Muslim Rule: Constantine and the Torah in the Melkite Arabic Chronicle of Agapius of Mabbug (Tenth Century)
}

\section{Introduction}

The word 'Melkite' comes from the Semitic root $m-l-k$, which gives the word for 'king' in Syriac (malkō) and Arabic (malik). The expression 'Melkite Christians,' therefore, means literally 'the Christians of the King.' It was coined in the late eighth-early ninth century to indicate those Christians living under Muslim rule - mostly in Egypt, Palestine and Syria - who shared the Chalcedonian, dyothelete faith of the Byzantine emperor. First attested in East Syrian (Nestorian) and Syrian Orthodox (Jacobite) sources, ${ }^{1}$ the term 'Melkites' was clearly born with a disparaging connotation, pointing at a supposed political loyalty to the emperor of Constantinople as well as at the acceptance of a creed that had been not only sanctioned, but forged by polit-

\footnotetext{
The research leading to this publication was funded by a FWO (Funds Wetenschappelijk Onderzoek) post-doctoral fellowship and represents a continuation of the work on Christian Arabic historiography I started as a post-doctoral researcher in Peter Van Nuffelen's project 'Memory of Empire: the Post-Imperial Historiography of Late Antiquity,' which received funding from the European Research Council under the European Union's Seventh Framework Programme (FP/2007-2013) / ERC Grant, agreement n. 313153. I first presented and discussed the subject of this paper at the workshop 'Text and Context in Late Antiquity,' organised by the Center for the Study of Christianity of the Hebrew University of Jerusalem on 14-15 February 2016. The subsequent research I carried out on it benefited substantially from the feedback and suggestions I received on that occasion.
}

1 Syrian Orthodox Christians who adopted Severus of Antioch's miaphysite doctrine are also called 'monophysites' or 'Jacobites' after Jacob Baradeus (c. 500 -578), the figure who most significantly contributed to the establishment and organisation of the Syrian Orthodox Church as an independent institution after the split caused by the Council of Chalcedon (451). East Syrian Christians, who adopted the dyophysite doctrine preached by Theodore of Mopsuestia, are also labelled 'Nestorians' after Nestorius, the bishop of Constantinople whose contested theological positions led to the Council of Ephesus in 431. The terms 'monophysites' and 'Nestorians,' although often still used in scholarship, have been pointed out as problematic and incorrect, see D. Winkler, "Miaphysitism: a New Term for Use in the History of Dogma and in Ecumenical Theology", The Harp 10 (1997), 33-40 and S.P. Brock, "The "Nestorian" Church: a lamentable misnomer", Bulletin of the John Rylands University Library of Manchester 78.3 (1996), 1-14.

Ә OpenAccess. (c) 2021 Maria Conterno, published by De Gruyter. (cc))BY-NC-ND This work is licensed under the Creative Commons Attribution-NonCommercial-NoDerivatives 4.0 International License. 
ical rulers. ${ }^{2}$ The monothelete controversy, which troubled the Byzantine Church for most of the seventh century, had eventually brought about a split in the eastern Chalcedonian communities with the birth of a separate church - the Maronite one - that rejected the dyothelete creed imposed by the Sixth Ecumenical Council of 680/1. ${ }^{3}$ Thereafter, the dyothelete Chalcedonians were left with the stigma of being 'the friends of the emperor'; for this reason, they came to be called, and then started to call themselves, 'Melkites.' It comes as no surprise then, that for the Melkites the figure of the Christian king was rich in symbolic import as much as in thorny implications, and it inevitably played a role in the process of self-definition and identity-building of their communities. This is evident, for instance, in the way in which Christian kings of ages past are treated in historiographical works. ${ }^{4}$ More precisely, the way in which Melkite historians remoulded the late antique historiographical and hagiographical material to portray certain Christian kings, and to thus shape their ideal Christian ruler, can be very telling about the present issues with which they were confronted and about the 'hottest topics' in their apologetic agenda.

A remarkable example of this is provided by a rather singular narrative concerning Constantine the Great contained in one of the earliest Melkite Arabic chronicles, the so-called Kitāb al-'unwān of Agapius of Mabbug. ${ }^{5}$ Agapius was the Melkite bishop of the city of Mabbug, ancient Hierapolis and modern-day Manbij in northern Syria. ${ }^{6}$ In the $940 \mathrm{~s}^{7}$ he wrote a universal chronicle in Arabic divided into two parts: from the Creation to Christ and from Christ to his own time (the latter preserved only up to the year 780). Agapius lived at the crossroads between Byzantium and the Islamic world, geographically as well as culturally. In the manuscripts he is referred to either as 'Agabius' or 'Mahbub (the Arabic equivalent) ibn Qustantin al-

2 On the origin, first attestations and spread of the term see S.H. Griffith, “'Melkites', 'Jacobites' and the christological controversies in Arabic in third/ninth century Syria”, in D. Thomas (ed.), Syrian Christians under Islam. The first thousand years, Leiden - Boston - Cologne 2001, 9- 55 (esp. 11-18). 3 A creed regarded as an unorthodox innovation and labelled by both Maronite and miaphysite sources as 'Maximianist heresy' (after Maximus the Confessor).

4 For a general overview of Melkite historiography before modern times, see J. Nasrallah, Histoire du mouvement littéraire dans l'église melchite du Ve au XXe siècle, Louvain - Paris 1979-1989, vol. II. t. 2, 49-55; vol. III. t. 1, 167-175; vol. III t. 2, 95-101.

5 The title Kitāb al- 'unwān (literally 'Book of the title') is due to the misreading of a corrupted line in the preface by one of the editors, Alexander Vasiliev. In the manuscripts, the work is presented as Kitāb al-ta'rīkh, 'Book of history,' or just Ta'rīkh, 'History.' It is accessible in two editions, both published at the beginning of the last century: L. Cheikho, Agapius episcopus Mabbugensis: Historia universalis / Kitāb al-'unwān (Corpus Scriptorum Christianorum Orientalium 65 - Scriptores Arabici 10), Paris 1912; A.A. Vasiliev, Kitab al-'unvan. Histoire universelle écrite par Agapius (Mahboub) de Menbidj (PO 5.4, 7.4, 8.3, 11.1), Paris $1910-1915$.

6 This piece of information is provided in the header of the only manuscript preserving the second part of the chronicle, the codex Florence, Biblioteca Medicea Laurenziana, Or. 323.

7 The terminus post quem of 941/2 CE can be gathered from one of the chronological summaries contained in the chronicle, where Agapius says that 330 years have passed since the beginning of Islamic rule. 
Rumi,' namely 'Agapius/Mahbub son of Constantine the Greek,' and his work provides many indications that he must have had a relatively good knowledge of Greek, if not even a Greek education. The tenth century witnessed the triumphal, albeit ephemeral, reconquest of Northern Syria by the Byzantine Empire. In the 920s, under the guidance of the Domestikos of the Scholai John Kourkouas, the Byzantine army had become - with changing fortunes - more resolutely aggressive against Muslim frontier strongholds and raided bases, including Theodosioupolis, Melitene, Samosata and Tarsus. The definitive capitulation of Melitene in 934 inaugurated a phase of successful and durable expansion, which gradually broke the resistance of the Hamdanid emir of Aleppo, Sayf al-Dawla, and brought within a few decades the reconquest of Crete (961), Cilicia and Cyprus (963-965), Mopsuestia and Tarsus (965), Antarados and Gabala (968), and eventually Antioch in 969. Aleppo was stormed, taken repeatedly, and turned into a semi-independent buffer state whose Muslim emir had to pay a tribute to the emperor and provide military support against the Fatimids. The Eastern frontier kept evolving until well into the eleventh century before it began eroding after confrontations with the Seljuk Turks and the annexations of Larissa/Shaizar (999), Edessa (1030) and Hierapolis/Manbij (1069). Although in Agapius' lifetime Manbij was still under Muslim control, Byzantium was literally around the corner and the whole region was beginning to gravitate again around Constantinople. This had of course implications for the Christians living there, particularly the Melkite Christians.

Although in communion with the Byzantine Church, the Melkites had soon developed a distinct cultural identity which set them apart both from the other Eastern Christians (Jacobites, Maronites, East Syrians) and from the Byzantine dyothelete Chalcedonians (Greek Orthodox). The main distinguishing feature was their use of the Greek patristic corpus while at the same time adopting Arabic for not only daily but also literary and religious uses. ${ }^{8}$ This gave birth to an Arabic-speaking but 'Greek-minded' hierarchy organised around the three patriarchates of Antioch, Jerusalem, and Alexandria. In the tenth century, when the Byzantine 'reconquista' of Northern Syria began, the process was already advanced enough to prevent the complete assimilation of Syrian Melkites to the Byzantine Church. Nonetheless, the reconquest of Antioch in 969 led to a certain degree of 're-Byzantinisation' of the patriarchate, especially visible in the liturgy, ${ }^{9}$ and to a revival of the Greek language. This inaugurated a long season of coexistence and competition between Greek and Arabic within the Melkite communities, with the former remaining the of-

8 See Griffith (cf. fn. 2).

9 See H. Kennedy, "The Melkite Church from the Islamic Conquest to the Crusades: Continuity and Adaptation in the Byzantine Legacy”, in The 17th International Byzantine Congress: Major Papers, New Rochelle - New York 1986, 325-343 (repr. in H. Kennedy, The Byzantine and the Early Islamic Near East, Burlington 2006, XII); K.-P. Todt, "Region und griechisch-orthodoxes Patriarchat von Antiocheia in mittelbyzantinische Zeit (969-1084)”, Byzantinische Zeitschrift 94 (2001), 239-267. For the parallel process in Jerusalem, see D. Galadza, Liturgy and Byzantinization in Jerusalem, Oxford 2017. 
ficial religious language even after the definitive withdrawal of the Byzantine Empire from the region, but the latter taking the lion's share in everyday life and literary production. ${ }^{10}$ Agapius, therefore, lived also at a turning point in the history of Syrian Melkites communities, when their process of self-definition was still a work in progress but a durable change was already looming large. The long passage on Constantine the Great presented and discussed in this paper bears clear signs of these specific historical, cultural, and social circumstances.

\section{The 'Septuagint-Tampering-Constantine’ Excursus}

The episode in question is not to be found in the part of the chronicle dealing with the reign of Constantine but is nested within a multi-layered flash-forward narrative about the translation of the Septuagint set by Agapius at the time of Abraham. When reporting the genealogy of the biblical patriarchs and its chronology, Agapius is very keen to stress the fact that the correct numbers of the patriarchal chronology are to be found only in the Greek translation of the Torah, whereas those contained in the Hebrew Torah and in the Syriac translation are wrong, having been altered by the Jewish High Priests at the time of Jesus. There are indeed various discrepancies between the biblical chronology attested in the Masoretic text of the Torah and in the Septuagint, which are well known and much studied, and remain a philological conundrum to date. ${ }^{11}$ Agapius introduces the story of the tampering at the very beginning, when he gives a first overview of Adam's descendants:

The following calculation appears in the translation of the Seventy wise men: it is written that Adam lived 230 years, then Seth was born to him, and from the day of Seth's birth to when Enosh was born to him 205 years [passed], and this makes 435 years. From Enosh's birth to when Cainan was born to Enosh 190 years [passed], which makes 625 years. From the day of Cainan's birth to when Malahalel was born to Cainan, 170 years [passed], and this makes 795 years. After Malahalel's birth Adam reached 930 years, which was the length of his life.

But according to what is in the Torah which is in the hands of the Jews - since they have tampered with and subtracted from it the years taken into account in the calculation of the chronology of the world, namely the years they subtracted from the patriarchs' lives before their sons were born (and the Torah of the Syrians comes from the Torah, because the Syriac Torah was translated from the Hebrew one after Christianity [came] and after the corruption [of the

10 This 'linguistic split' eventually led the Melkites to separate from the Greek Orthodox Church and to seek in 1729 the union with the Catholic Church of Rome, which allowed them to abandon Greek and have their own liturgy in Arabic.

11 For recent, comprehensive discussions of the question see G. Larsson, "The Chronology of the Pentateuch: A Comparison of the MT and LXX," Journal of Biblical Literature 102 (1983), 401-409; J. Hughes, Secrets of the times: myth and history in biblical chronology, Oxford 1990; D.V. Etz, "The Numbers of Genesis V 3-31: A Suggested Conversion and its Implications," Vetus Testamentum 43 (1993), 171-189; M. Rösel, Übersetzung als Vollendung der Auslegung: Studien zur Genesis-Septuaginta, Berlin (1994), 129-144. 
text]) - it is written in it that Adam lived until the ninth generation of the sons of his sons, that is until the year 56 from the birth of Lamek son of Enoch, because they subtracted from the years of Adam and of other patriarchs 100 years before the birth of their sons and they added them to the years of their lives after the birth of their sons. The Jewish priests Annas and Caiaphas wanted to deny the advent of the Messiah and [they said] that the time when he would come had not arrived yet. According to the timespan in the Hebrew Torah, then, in what they recorded and wrote [we read] that Adam lived 130 years and gave birth to Seth; from Seth's birth to Enosh's, 105 years; from Enosh's birth to Cainan's, 90 years; from Cainan's birth to Malahalel, 70 years; from Malahalel's birth to Jared, 65 years [...]. ${ }^{12}$

He continues to narrate the biblical history more in detail, providing for each of the patriarchs the total years of life and the age of begetting ${ }^{13}$ according to both the Septuagint and to what he calls the 'manipulated, 'altered,' or 'false Torah of the Jews' which, he regularly adds, was translated and adopted by Syriac Christians. ${ }^{14}$ When he reaches the time of Abraham, he explains once more the reasons of such discrepancies between the Greek and the Hebrew/Syriac text of the Bible, inserting in his narrative a long, multi-layered flash-forward, which can be summarised as follows. ${ }^{15}$

After Jesus' death and resurrection, the Jewish High Priests Annas and Caiaphas tampered with the biblical chronology in order to prove, according to the Sacred Scriptures, that the time of the Messiah was yet to come and therefore, that Jesus of Nazareth could not be the Christ. They shrank the chronology of the biblical patriarchs from Adam to Abraham, counting on the fact that no one had a good enough knowledge of such a remote past to discover the ruse. They altered the original Hebrew text of the Torah, but in the Temple of Jerusalem a copy was also kept of the Greek translation of the Scriptures made in Alexandria almost 300 years before by Ptolemy II's request. This triggers, within the flash-forward, a flash-back to the story of the translation of the Septuagint, which Agapius reports by largely following the traditional version of the Letter of Aristeas. At the end of it, we see King Ptolemy sending out copies of the Greek translation to the major cities of the Mediterranean (Rome, Ephesus, Byzantium), with one brought back to Jerusalem by the Seventy-two translators in person:

The wise translators asked him for one of those copies, in order to boast about it with their fellows. He granted it to them, and this was a providential disposition of God's, because he foresaw

12 A.A. Vasiliev, Kitab al-'unvan. Histoire universelle écrite par Agapius (Mahboub) de Menbidj, (PO 5.4), Paris 1910, 561-562.

13 Namely the age at which his first son, or the son who continued the genealogical line, was born. The age of the world was calculated by summing up the age of begetting of all the biblical patriarchs from Adam down to Jesus.

14 Vasiliev (cf. fn. 12) 573, 580-582, 586-589, 595, 598, 599, 629-631, 634-635.

15 The excursus takes up more than 20 pages in Vasiliev's edition: Vasiliev (cf. fn. 12) 636-660. It includes also a résumé of Alexander the Great's feats, which led to the establishment of the Ptolemaic kingdom in Egypt. 
and knew in advance, in his knowledge, the iniquitous deeds of their priests and governors, Annas and Caiaphas, and their fellows, against the Messiah at the moment of his appearance. ${ }^{16}$

After that, Agapius repeats in even more detail the story of the tampering and concludes:

Today it [i.e., the altered Torah] is in the hands of those Christians who use the Syriac idiom, and the true Torah translated by the Seventy was not shown to them until Constantine reigned, son of Helena the believer, whose reign was 305 years after the advent of the Messiah. ${ }^{17}$

These words trigger one more jump forward in time, starting the narrative about Constantine. According to Agapius, Constantine went in person to Jerusalem in search of the relics of Christ and of the books of the Prophets. Some of the Jews, afraid that the truth about the tampering would be discovered, decided to get ahead of the game by leaking the story of the tampering to the emperor. The emperor then summoned the High Priests and asked for an explanation, but they denied everything stubbornly, so he jailed them and had the copies of the Greek translation fetched from Alexandria, Rome and the other cities. Once they became aware of this, the High Priests decided to confess in order to have their life spared and they gave their copy of the Septuagint to the Emperor. Constantine compared all the Greek copies with the Hebrew one and he found out that the Hebrew text had actually been tampered with, and that only the Septuagint preserved the original text of the Torah. Since the Jews kept putting forward lame excuses, he convoked some Christian bishops and ordered them to counter the Jews' arguments in a dispute. The bishops smashed the Jews' versions by revealing the whole truth that had been hidden for centuries, providing further proof in a chronological exegesis of Daniel's prophecy of the 70 weeks (Dn 9:24-27), from which the exact date of the Messiah's arrival can be calculated. The long digression ends as follows:

As the altered Torah and all the books of the Prophets that are in possession of the Christians in Syriac copies are spread in all the parts of the earth from East to West, the Christians are not able [to explain] the cause of this shortcoming in its translation and the reasons of the issue, but [as for] all the scholars and wise men and whoever tried to translate the books of the Prophets by interpreting and rendering them from one language to another, or to explain their meaning and interpret their content, they did not change anything in it, or their translation is based on the Syriac Scriptures, which are at odds with what is in the translation of the Seventy, in what the Jews altered and changed after the resurrection of the Messiah. ${ }^{18}$

16 Vasiliev (cf. fn. 12) 644-645.

17 Vasiliev (cf. fn. 12) 647.

18 Vasiliev (cf. fn.12) 659-660. 


\section{The Apparent Targets: Syriac Christians and Jews}

In just one sentence, Agapius dismisses centuries of exegesis and biblical studies in Syriac, because they were based on an altered biblical text, namely the Syriac translation made on the Hebrew original and known as the Peshitta. Such an inherent vice implicitly calls into question the whole theological thought of Syrian Orthodox and East Syrian Christians, who are clearly one of the targets of this digression. Syriac, though, was not exclusively the language of Jacobites and Nestorians: in pre- and early Islamic time it was in fact spoken and used in the liturgy by eastern Chalcedonians as well, ${ }^{19}$ and was still being used as liturgical language by some Melkites even at the time of Agapius and later. This is suggested by a number of Melkite lectionaries produced in the monasteries of the Black Mountain, near Antioch, during the second Byzantine domination of Northern Syria. These are Syriac translations of Byzantine liturgical books in which everything is remarkably translated from Greek except for the Biblical pericopes, whose text matches the Peshitta. ${ }^{20}$ These lectionaries attest on the one hand to the process of 'Byzantinisation' of Melkite liturgy inaugurated by the reconquest of Antioch and on the other hand to a certain resilience of Syriac as a religious language among the Melkites. Between the lines of Agapius' text, therefore, we can also read an appeal to those Melkite Christians who were still using the Syriac translation of the Bible, thus sharing such an important identity marker as language with heretics rather than with the orthodox Chalcedonians. John Lamoreux, who has recently translated and commented on the 'Septuagint-Tampering-Constantine' excursus in a source-book for the history of Melkite Christianity, ${ }^{21}$ argues that Agapius must have found the whole narrative block in a Syriac source and just translated and incorporated it in his chronicle. The narrative would have been originally part of a treatise addressing both Chalcedonian and non-Chalcedonian Syriac Christians with the aim of convincing them to abandon the Syriac translation of the Scriptures

19 On the Greek-Syriac bilingualism of eastern Christians see S.P. Brock, "Greek and Syriac in Late Antique Syria", in A.K. Bowman and G. Woolf (eds.), Literacy and Power in the Ancient World, Cambridge - New York 1994, 149-160. More specifically on Greek and Syriac among eastern Chalcedonians/Melkites: S.H. Griffith, "From Aramaic to Arabic: the Languages of the Monasteries of Palestine in the Byzantine and Early Islamic Periods", DOP 51 (1997), 11-31; S.P. Brock, "Syriac into Greek at Mar Saba: The Translation of St. Isaac the Syrian," in J. Patrich (ed.), The Sabaite Heritage in the Orthodox Church from the Fifth Century to the Present, Louvain 2001, 201-208; A.M. Butts, Language Change in the Wake of Empire: Syriac in Its Greco-Roman Context (Linguistic Studies in Ancient West Semitic 11), Winona Lake, IN 2016.

20 See S.P. Brock, "Syriac Manuscripts copied on the Black Mountain, near Antioch", in R. Schulz and M. Görg (eds.), Lingua Restituta Orientalis: Festgabe für Julius Assfalg, Wiesbaden 1990, 59-67. 21 J.C. Lamoreux, "Agapius of Manbij”, in S. Noble - A. Treiger (eds.), The Orthodox Church in the Arab World 700-1700, DeKalb IL 2014, 136-159. 
based on the Hebrew text in favour of one based on the Septuagint. ${ }^{22}$ This hypothesis raises the important question of the competition among the different translations of the Bible in late antique eastern Christian communities, a question that goes beyond the scope of the present paper. ${ }^{23}$ Regardless of its origin, however, Agapius' re-use of this narrative in his Arabic chronicle responds to his own agenda and results in a sweeping vilification of the Syriac language and of Syriac Christianity altogether.

The anti-Jewish aim of the story is plain, too, and here Agapius is not proposing anything new. Not only was the mutual accusation of tampering with the Scriptures a long-standing topos in Christian-Jewish polemics, ${ }^{24}$ but Muslims would soon appropriate this topos and use it against both Jews and Christians. The accusation of tahriff (falsification) addressed to the 'People of the Book' is in fact already present in the Quran, ${ }^{25}$ and the Iranian polymath Al-Biruni (973-1048), who wrote some fifty years after Agapius, seems to sketch the very scenario in which Agapius's excursus originated. In his Chronology of Ancient Nations, he discusses the differences between the Jewish and Christian computations of the world era and their mutual accusations of inaccuracy, finding faults with both:

The Jews and Christians differ widely on this subject; for, according to the doctrine of the Jews, the time between Adam and Alexander is 3,448 years, whilst, according to the Christian doctrine, it is 5,180 years. The Christians reproach the Jews with having diminished the number of years with the view of making the appearance of Jesus fall into the fourth millennium in the middle of the seven millennia, which are, according to their view, the time of the duration

22 Namely the so-called Syro-Hexapla, a translation based on the Septuagint column of Origen's Hexapla produced by Paul of Tella in 617; see A.G. Salvesen, "Syro-Hexapla", in S.P. Brock - G. Kiraz, A.M. Butts - L. Van Rompay, Gorgias Encyclopedic Dictionary of the Syriac Heritage, 394-395. 23 I discuss this issue, as well as various hypotheses on the origin of the excursus, in M. Conterno, "Found in translation: Agapius, the Septuagint, and the 'falsified' Torah of the Jews", in M. Conterno - M. Mazzola (ed.), Intercultural Exchange in Late Antique Historiography, Leuven 2020, 143-167. See also R.B. ter Haar Romeny, "The Peshitta and its Rivals. On the Assessment of the Peshitta and Other Versions of the Old Testament in Syriac Exegetical Literature”, The Harp 11-12 (1998-1999), 21-31. 24 See S. Benoit, "L'inspiration des Septante d'après les Pères de l'église”, in L'homme devant Dieu. Mélanges H. Lubac, 3 vols., Paris 1963, vol. I, 169-187; W., Adler, "The Jews as falsifiers: charges of tendentious emendation in anti-Jewish Christian polemic", in D. Goldenberg (ed.), Translation of Scriptures: Proceedings of a Conference at the Annenberg Research Institute, May 15, 1989, Philadelphia 1990, 1-27; Y. Moss, "Versions and Perversions of Genesis: Jacob of Edessa, Saadia Gaon and the Falsification of Biblical History", in A.M. Butts - S. Gross (eds.), Syriac Christianity and Judaism. Intersections across the First Millennium, Tübingen 2020, 207-231; Conterno (cf. fn. 23) 151-158.

25 See J.-M. Gaudeul - R. Caspar, "Textes de la tradition musulmane concernant le tahrinf (falsification) des Écritures”, Islamochristiana 6 (1980), 61-104; G.S. Reynolds, “On the Qur’anic accusation of Scriptural Falsification (tahriff) and Christian Anti-Jewish Polemic", Journal of the American Oriental Society 130.2 (2010), 189-202; D. Thomas, "The Bible in Early Muslim Anti-Christian Polemic”, Islam and Christian-Muslim Relations 1 (1996), 29-38; C. Adang, "Medieval Muslim Polemic against the Jewish Scriptures", in J. Waardenburg (ed.), Muslim Receptions of Other Religions. A Historical Survey, Oxford - New York 1999, 143-168. 
of the world, so as not to coincide with that time at which, as the prophets after Moses had prophesied, the birth of Jesus from a pure virgin at the end of time was to take place. ${ }^{26}$

He rejects the Christian numerological interpretations of Daniel's prophecy based on the Syriac language because the original language of the prophetical revelation was Hebrew, but he also replies to the claims of superiority of the Septuagint:

Now this [i.e., the Greek translation ordered by Ptolemy] is the copy of the Christians, and people think that in it no alteration or transposition has taken place. The Jews, however, give quite a different account, viz. that they made the translation under compulsion and that they yielded to the king's demand only from fear of violence and maltreatment, and not before having agreed upon inverting and confounding the texts of the book. ${ }^{27}$

Al-Biruni eventually argues that, historically, the only uncorrupted text of the Torah should be the Samaritan one. If read against the backdrop of Muslim accusations of tahrîf, Agapius' blame game seems therefore meant to turn the tables on the Jews in order to clear the Christians of such accusations. And since the attack to the Jews implied an attack to Syriac Christians as well, the Melkites are implicitly the only ones who come out clean from the whole tahrîf affair.

The possible targets of this digression, and the context that urged Agapius to deal in such an extensive way with the inconsistencies of biblical chronology, seem therefore clear. Besides putting forth the above apologetic function, Agapius' concern for chronological accuracy also responds to the nature of the work he was writing and reflects his approach to history. The attention paid to absolute and relative chronology and to chronological questions - such as the date of the Creation, the world's age, the date of the Incarnation, the date of the end of times - has been long recognised as a specific feature of Christian universal histories, and Agapius is no exception to that. ${ }^{28}$ What is more, at the end of the first part of his work Agapius claims that he will carry on his narrative "until the moment of the end of the world and the termination of the years of the world, based on what the Prophets

26 C.E. Sachau, The Chronology of Ancient Nations: an English version of the Arabic text of the Athârul-Bâkiya of Albîrûnî, London 1879, 18.

27 Sachau (cf. fn. 26) 24. Al-Biruni is referring here to one of the Rabbinic versions of the Septuagint story, according to which the Seventy intentionally inserted changes in their translation because they did not want the true word of God to fall into the hands of the pagans. See E. Tov, "The Rabbinic tradition concerning the 'alterations' inserted into the Greek Pentateuch and their relation to the original text of the LXX", Journal for the Study of Judaism 15 (1984), 65-89.

28 W. Adler, Time Immemorial: archaic history and its sources in Christian chronography from Julius Africanus to George Syncellus, Washington, D.C. 1989; B. Croke, "The origins of the Christian World Chronicle", in B. Croke - A.M. Emmett (eds.), History and Historians in Late Antiquity, Sydney 1983, 116 - 131 ; repr. in B. Croke, Christian Chronicles of Byzantine history, 5th-6th centuries, Aldershot 1992, VI; A. Marsham, "Universal Histories in Christendom and the Islamic World, c. 700 - 1400", in S. Foot - C.F. Robinson (eds.), The Oxford Handbook of Historical Writing. Volume 2: 400-1400, Oxford 2012, 431-456. 
and God's revealed books say on this regard, according to what reason and logic dictate." 29 Unfortunately the final part of the chronicle is missing, but in view of this passage one should assume that it was not just limited to the author's time: it even contained an eschatological section, thus possibly representing the only example of a 'full' universal history covering the entirety of the world's lifespan. Chronological accuracy understandably assumes an exceptional importance in his chronicle, which clarifies even better Agapius' insistence on the interpretation of Daniel's prophecy of the 70 weeks and on the (according to him) correct and incorrect numbers of Genesis' genealogy. Still, the role of Constantine in all this remains somewhat baffling.

\section{A Story of Interwoven Echoes}

The narrative concerning Constantine is a medley of themes taken from the hagiographical tradition on Constantine and Helena, most of which are very easy to recognise. No visit of Constantine's to Jerusalem is historically attested, and no hagiographical tradition contains one either, but the emperor's trip to the Holy City in search of Christ's relics clearly parallels the story of the Inventio Crucis, Helena's mission to recover the True Cross narrated in the Greek ecclesiastical histories. ${ }^{30}$ The Inventio Crucis generated in the East a variant called the Judas Ciriacus Legend, preserved only in Syriac, and a 'twin legend' (reported, too, by Agapius in the second part of the chronicle ${ }^{31}$ ) according to which the relic of the Cross was first discovered by Protonike, the converted wife of the Emperor Claudius. The Jews' leaking the tampering story and the High Priests' stubbornly denying it mirror antithetically the Judas Ciriacus Legend in which the Jews deny knowing where the Cross is hidden but eventually one of them, Judas, reveals the secret to Helena and becomes Christian with the name of Ciriacus. ${ }^{32}$ Constantine's order to fetch the copies of the Septuagint from various cities across the Mediterranean echoes an episode with a stronger historical background, namely Constantine's request to produce fifty copies of the Scriptures for the churches of Constantinople, attested by Eusebius in his Life of Constantine..$^{33}$ Finally, the dispute between the bishops and the High Priests recalls

29 A.A. Vasiliev, Kitab al-'unvan. Histoire universelle écrite par Agapius (Mahboub) de Menbidj (PO 11.1), Paris 1915, 144.

30 Socr., hist. eccl. 2.17; Sozom. 2.1; Theod., hist. eccl. 17.

31 A.A. Vasiliev, Kitab al-'unvan. Histoire universelle écrite par Agapius (Mahboub) de Menbidj (PO 7.4), Paris 1911, 487-488. On the Judas Ciriacus and the Protonike Legend see J.W. Drijvers, Helena Augusta: The Mother of Constantine the Great and the Legend of her Finding of the True Cross, Leiden 1992.

32 J.W. Drijvers, The Finding of the True Cross: The Judas Kyriakos Legend in Syriac. Introduction, Text and Translation (CSCO 565), Leuven 1997.

33 Euseb., vita Const. 34-37. On the parallel between the two narratives see A. Wasserstein - D. Wasserstein, The Legend of the Septuagint from Classical Antiquity to Today, Cambridge 2006, 150 - 151. 
the Actus Sylvestri, the legend of Constantine's healing, conversion and baptism by Pope Sylvester in Rome. Constantine has Sylvester confront twelve rabbis in a public debate after the Jews try to convince Constantine that their God and not Christ has performed the miracle that healed him; the debate is won triumphantly by the Pope. Interestingly, in an eastern variant of the legend, preserved by Agapius himself and by the Chronicle of Seert (a tenth-century East Syrian ecclesiastical history in Arabic), Constantine summons twelve Christian bishops, instead of Sylvester alone, to debate against the rabbis. ${ }^{34}$ Other disputes present in the Constantinian tradition are also called to mind, such as the one already mentioned between Helena and the Jews in the Judas Ciriacus Legend, or the dispute between Constantine himself and the pagan priests following Constantine's vision of the Cross in the sky, preserved in a Syriac liturgical poem on the finding of the Cross. ${ }^{35}$ Agapius' narrative seems indeed a composition of already existing materials skilfully tailored to a new context - very much like the Arch of Constantine in Rome.

Besides recalling various elements of the Constantinian saga, the story of Constantine's recovery of the Septuagint also parallels other accounts centred on the re-discovery of lost or hidden wisdom by a virtuous king, the most conspicuous precedent being the biblical king Josiah. ${ }^{36}$ According to the second book of Kings and the second book of Chronicles, ${ }^{37}$ during the restoration of the Temple of Jerusalem ordered by Josiah the workers found the Book of the Law (namely the Torah, or possibly just Deuteronomy), which had been disregarded and totally forgotten by the Jews. The 'Septuagint-Tampering-Constantine excursus' in Agapius presents some significant points of contact with the story of Josiah. When the book found in the Temple is brought to him, Josiah immediately consults the most reliable religious authority, the prophetess Hulda, who tells him that after Moses's death the people of Israel had been led astray and ignored God's commandments; likewise Constantine, once he has received the copies of the Septuagint and compared them with the Hebrew Torah, summons the Christian bishops who reveal to him how the authentic word of God had remained hidden since Jesus' time by explaining the discrepancies and instructing him on the meaning of Daniel's prophecy of the seventy weeks. After receiving the prophetess' response, Josiah renews the long-forgotten Covenant between Israel and the Lord and has the people pledge themselves to it. Similarly,

34 Vasiliev (cf. fn. 29) 543; A. Scher, Histoire nestorienne (Chronique de Seert), Part I.1 (PO 4.3), Paris 1908, 262. On the various versions of the Actus Sylvestri see T. Canella, Gli 'Actus Sylvestri'. Genesi di una leggenda su Costantino Imperatore, Spoleto 2006.

35 See S.P. Brock, "Two Syriac Poems on the Invention of the Cross," in N. el-Khoury - H. Crouzel R. Reinhardt (eds.), Lebendige Überlieferung: Prozesse der Annäherung und Auslegung. Festschrift für Hermann-Josef Vogt zum 60. Geburtstag, Beirut - Ostfildern 1992, 55-82; repr. in S.P. Brock, From Ephrem to Romanos. Interactions between Syriac and Greek in Late Antiquity (Variorum Collected Studies Series CS664), Aldershot - Brooksfield, VT 1999, XI.

36 Another example is the discovery of the works of Dictys of Crete by the Emperor Claudius, narrated in Ioh. Mal.10.28.

372 Kgs 22:8-23:3 and 2 Chr 34:14-28. 
the Jews' plot is exposed and the 'true Torah' is handed out to the world again after Constantine's intervention. An implicit anticipation of Josiah's story can be found in Deuteronomy, where we read that after having written the Book of the Law, Moses foresees the Jew's future disobedience and fall into sin and orders the Book of the Law be preserved beside the Arc of the Covenant so that it would be found again and remind the Jews of their misconduct. ${ }^{38}$ Similarly, Agapius says that it was thanks to the Lord's Providence that one of the copies of the Septuagint was brought to Jerusalem and preserved in the Temple because God already knew that the Jews were going to crucify Christ and then tamper with the Holy Scriptures to hide the truth. In Agapius' narrative, therefore, Constantine reduplicates the biblical model of the pious king predestined to bring back to light the word of God after it has been obliterated by the sinful Jews. Oddly enough, Josiah is presented only very briefly in his chronicle and his re-discovery of the Book of the Law is not mentioned at all, ${ }^{39}$ leaving no intra-textual parallel between the two figures. We can assume that Agapius relied on his readers' knowledge of biblical history and thought that the association between Constantine and his biblical precedent would be clear even if he did not tell Josiah's story in the chronicle. Or, on the contrary, he intentionally avoided the doublet, as it were, and simply transferred Josiah's role to Constantine, in order to make the latter the only providential 're-discoverer of God's word' in world history. But again: why Constantine?

\section{Constantine's (Difficult) Legacy}

The star of Constantine the Great had never gone down in the Christian world, but in tenth-century Byzantium the figure of the first Christian emperor was experiencing a particularly significant revival. Constantine was a key figure in the propaganda of the Macedonian dynasty, especially under his namesake, the learned emperor Constantine VII Porphyrogennetos (945-959). ${ }^{40}$ The dynasty’s founder, Basil I (867-886), had already been associated with Constantine the Great in eulogies and iconography

38 Dt 31:26-29 (New International Version): "Take this Book of the Law and place it beside the Ark of the Covenant of the Lord your God. There it will remain as a witness against you. For I know how rebellious and stiff-necked you are. If you have been rebellious against the Lord while I am still alive and with you, how much more will you rebel after I die! Assemble before me all the elders of your tribes and all your officials, so that I can speak these words in their hearing and call the heavens and the earth to testify against them. For I know that after my death you are sure to become utterly corrupt and to turn from the way I have commanded you. In days to come, disaster will fall on you because you will do evil in the sight of the Lord and arouse his anger by what your hands have made."

39 Vasiliev (cf. fn. 29) 203.

40 See A. Markopoulos, "Constantine the Great in Macedonian historiography: models and approaches”, in P. Magdalino (ed.), New Constantines. The Rhythm of Imperial Renewal in Byzantium, 4th-13th centuries, Aldershot 1994, 159-170. 
during his lifetime ${ }^{41}$ but once the dynastic line was well established, Basil's humble origins and the irregular way in which he had taken the throne (that is, by murdering his predecessor Michael III) became among the main stumbling blocks for imperial ideology. Constantine VII went so far as to ascribe to Basil's mother a blood-link with none the less than Constantine the Great, claiming thus for his grandfather (and for himself) not just noble ancestry but the highest imperial legitimacy. ${ }^{42}$ In his dynastic propaganda - which influenced, directly or indirectly, the whole contemporary literary production - Porphyrogennetos presented himself not just as a descendant of Constantine I, but as the Constantine the Great of his own time. The impact of the Macedonian propaganda was not limited to Constantinople or to the borders of the Byzantine Empire: the 'rumour' of Constantine VII's family relation to Constantine the Great reached the West thanks to Liutprand of Cremona's Antapodosis ${ }^{43}$ and the imperial Constantinian ideology also boosted the ongoing reconquest of Northern Syria. The transfer of the Holy Mandilion from Edessa to Constantinople after the siege of the city in 944, for instance, was presented as a parallel to the retrieval of the relics of the cross by Helena. ${ }^{44}$ Agapius was writing precisely in that region in those very years, ${ }^{45}$ and the Melkites on both sides of the advancing border were likely to be the most immediate recipients of Byzantine propaganda. This should be definitely taken into account when trying to understand the origin of the 'SeptuagintTampering-Constantine' narrative and Agapius' reasons for including it in his chronicle. But in order to produce an entirely compelling explanation to the involvement of Constantine in the 'Septuagint-Tampering' story, we need to look at the Islamic and the Syriac traditions as well.

Constantine the Great was considered by Muslim historians as the first Byzantine emperor, and he was often placed side by side with Ardashir, the founder of the Sassanid dynasty, as one of the most important kings of pre-Islamic times. ${ }^{46}$ Yet he is not presented in a completely positive light by the Islamic tradition. Muhammad was the

41 Markopoulos (cf. fn. 40) 160-162.

42 Vita Basilii, in Theophanes Continuatus 215.

43 Liutprand of Cremona, Antapodosis 1.7.

44 See A. Cameron, "The History of the Image of Edessa: the Telling of a Story", in C. Mango - O. Pritsak - U.M. Pasicznyk (eds.), Okeanos: Essays presented to Ihor Sevcenko on his Sixtieth Birthday by his Colleagues and Students, Cambridge, MA, 1984, 80 -94; Markopoulos (cf. fn. 40) 165.

45 The terminus post quem of $941 / 2 \mathrm{CE}$ is given by one of the chronological summaries provided by Agapius in the chronicle, whereas al-Mas'udi's citation of the chronicle in his Book of Admonition and Revision, written around 956, provides the terminus ante quem.

46 On Constantine the Great in the Islamic tradition, see N.M. El-Cheikh, "The conversion of Constantine the Great: a reading of Arabic-Muslim sources”, in Journal of Turkish Studies 36 (2011), 69-83 and M. Di Branco, Storie Arabe di Greci e di Romani. La Grecia e Roma nella storiografia arabo-islamica medievale, Pisa 2009, 136-142. For a more detailed study of the representation of Constantine in Arabic (both Islamic and Christian) historiography see J. Stutz, Constantinus Arabicus. Die arabische Geschichtsschreibung und das christlische Rom, Piscataway NJ 2017, who also comments briefly upon Agapius' excursus (83-90, with partial German translation). 
'Seal of the Prophets' and his revelation stands in continuity both with the Jewish and the Christian ones but also with the intention to correct them since both have been perverted in the course of time. Christians and Constantine, in particular as convener of the council of Nicaea, were open to criticism because church councils regularly introduced major deviations from Jesus' doctrine and the contents of the Scriptures. Particularly relevant for our understanding of Agapius' digression is the anti-Christian treatise written by the Muslim theologian 'Abd al-Jabbar ibn Ahmad, entitled The Establishment of Proofs for the Prophethood of Our Master Mohammad. ${ }^{47}$ One of 'Abd al-Jabbar's main polemical points against the Christians is that they perverted Christ's original doctrine, moulding their religion to make it more palatable to the Romans out of pure political opportunism. He accuses the Christians of abandoning the Hebrew language and adopting Greek in order to cover their manipulations of the Scriptures and the Gospels and he claims that the full 'Romanisation' of the Christian doctrine was achieved precisely under Constantine, with the council of Nicaea. About the council he says: ${ }^{48}$

For this reason 318 men were assembled in Nicaea in the land of the Romans, and they established the doxology of the creed which I have already quoted. They submitted the creed to Constantine, who accepted it and imposed it upon his subjects, killing those who refused to accept it. The recusants were forced to make a show of accepting the creed, out of fear of the sword, and all the other formulas were abolished. Those who followed the [true] religion of Christ were persecuted, forced to venerate the cross, eat pork, and follow the religious practices of the Romans.

And again, simulating a dispute with the Christians:

If they say 'We accept what they say because they have performed miracles,' we can point to the preceding account in which we have shown that the whole business began with Constantine the son of Helena, that Christ had taught them to observe the law of Moses and follow the practices which himself had shown them during his lifetime [...]. The story of their abandonment of these doctrines can be found in their book called the Acts of the Apostles and in their Synod.

'Abd al-Jabbar is the first Muslim author to put forward such polemical arguments against the Christians, at least to our knowledge. He was born in 935, therefore he was active at least one or two generations after Agapius. It is admittedly difficult to tell what in his work is innovative and what instead comes from already circulating polemical topoi. Yet, very similar allegations on the part of the Muslims can be inferred from earlier Christian Arabic apologetics. Sydney Griffith, for instance, has argued that Theodore Abu Qurrah's very specific arguments in his treatise On Or-

47 'Abd al-Jabbar, Tathbit dala'il-Nubuwwat Sayyidina Muhammad, ed. 'A. 'Uthman, 2 vols., Beirut 1966. On 'Abd al-Jabbar and his work see G.S. Reynolds, A Muslim Theologian in the Sectarian Milieu: Abd al-Jabbar and the Critique of Christian Origins, Leiden 2004.

48 An English translation and discussion of the relevant passages can be found in S.M. Stern, "Abd al-Jabbār's account of how Christ's religion was falsified by the adoption of Roman customs”, JThS 19 (1968), 128-185, esp. 145, 151. 
thodoxy (late eighth/early ninth century) allow us to deduce that he was countering, among many attacks, an attempt to demean Melkite doctrines by alleging that they were derived from the authority of the Byzantine emperor rather than from the Bible; he also pointed precisely to the church councils as the fateful tool of distortion of the true religion. ${ }^{49}$ Theodore writes for instance:

It is necessary for the church to praise Christ, since he made the kings subject to her, that they might serve her fathers and her teachers, because every king in whose time one of these councils convened, was one of the most pious of all, since he supported it by hosting it and restrained the divisions in it so that the fathers might be able to investigate into the religion with protection and composure and to carry out its decision. As far as the king himself is concerned, it did not belong to him to investigate into the religious matter or to confirm the decision about anything. He was merely a servant to the fathers, listening to them obediently and accepting whatever they decided in the religious matter without participating with them in any of the investigations..$^{50}$

Likewise, the Arab Jacobite Habib ibn Khidma Abu Ra'ita al-Takriti (c. 770-c. 835) devoted a large section of his brief treatise entitled The Refutation of the Melkites concerning the Union [of the Divinity and Humanity in Christ] to defend the emperors who convened the first three ecumenical councils, especially Constantine, presenting him as the one who made it possible for the council Fathers to define the true faith thus protecting the Church and the Christian doctrine from the lies of the heretics. ${ }^{51} \mathrm{Abu}$ Ra'ita's treatise was written as a letter addressed to the Armenian ruler Ashot ibn Sambat Msaker with the aim of countering precisely Theodore Abu Qurrah's attempt at converting the miaphysite Armenians to Chalcedonian Christianity. Sandra Toenies Keating's thorough analysis of the text, though, has demonstrated that Abu Ra'ita expected his letter to be read or heard by Muslims as well ${ }^{52}$ and that some of his arguments (including the fervent apology of Constantine) can only be explained as responses to the attacks of Muslim controversialists against the Christians. Besides corroborating what can be inferred from Theodore Abu Qurrah's treaty On Orthodoxy, Abu Ra'ita's letter shows that not only the Melkites, but also non-Chalcedonian Christians, felt that in the light of the fifth-century developments the image of Constantine as the first convener of a church council was somehow problematic and needed to be claimed and justified. The Syriac tradition shows that this was already the case before Constantine and the church councils became the target of Muslim criticism.

49 S.H. Griffith, "Muslims and Church Councils: the Apology of Theodore Abū Qurrah", Studia Patristica 25 (1993), $270-299$.

50 Translation by Griffith (cf. fn. 49) 289.

51 S. Toenies Keating, "Habīỉ ibn Khidma Abū Rā'ița al-Takrîtī's 'The Refutation of the Melkites concerning the Union [of the Divinity and Humanity in Christ]' (III)", in D. Thomas (ed.), Christians at the heart of Islamic rule: church life and scholarship in 'Abbasid Iraq, Leiden - Boston 2003, 39-53. 52 Toenies Keating (cf. fn. 51) 45-48 (see esp. fn. 53). 
The so-called Canons of Marutha of Maipherqat - the Syriac canons allegedly issued from the synod held in Seleucia-Ctesiphon in 410 - are transmitted together with a small corpus of narratives on Constantine and Helena. These include an account of the council of Nicaea that presents us with a highly symbolic scene in which Constantine gives his ring, his sceptre, and his sword to the 318 bishops saying: "Behold, today power is given to you on the whole Church, the clergy, and the Empire, and to all the ranks that are subjected to the clergy and the empire. God will deem you responsible for the salvation or perdition of all the Church's sons." 53 This very passage, in which Constantine literally gives carte blanche to the bishops on both religious and political matters, clearly aims at freeing him from the blame of having interfered with doctrinal matters while implicitly setting a benchmark for his successors and implicitly condemning those who did not follow his example. ${ }^{54}$ Although these materials are preserved exclusively in the East Syrian tradition, it has been argued that the sections pertaining to Helena and to the council of Nicaea originated in the miaphysite circles around Rabbula of Edessa in the years 430 $440 .^{55}$ This apologetic picture of Constantine, therefore, circulated across the various Syriac traditions and in addition to defending the reputation of the first Christian king, it also worked - very conveniently - as an implicit legitimation of the existence of Christian Churches that did not respond to a Christian king. In contrast is the unapologetic judgement of John of Phenek, who does not even take the trouble of clearing Constantine's name. On the contrary, the seventh-century East Syrian author explicitly points his finger at the council of Nicaea as the door through which dispute and corruption entered the Church, and he depicts all Christian kings in a very negative light:

There had been many gatherings of bishops prior to that at Nicaea, but they had not been ecumenical, and their aim was not to make a new creed, [...]. But once there was respite, and believing kings held sway over the Romans, it was then that corruption and intrigues entered the churches, and there were a great many creeds and assemblies of bishops, seeing that each year they made a new creed. Peace and quiet thus brought considerable loss upon them, for lovers of

53 A. Vööbus (ed. and transl.), The Canons ascribed to Mārūtā of Maipherqaț and related sources (CSCO 439-440, Scriptores Syri 191-192), 2 vols., Leuven 1982, 107 (transl.), 135 (Syriac text). The same account of the Council of Nicaea is contained also in Barhadbeshabba 'Arbaia's ecclesiastical history, see F. Nau (ed. and transl.), Première partie de l'Histoire de Barhadbešabba Arbaya (PO 23.2), Paris 1932, 207.

54 For a broader analysis see M. Conterno, "Culto e memoria di Costantino nelle chiese sire. Agiografia costantiniana nella liturgia e nella storiografia siriaca", in A. Melloni - P. Brown et al. (eds.), Flavius Valerius Constantinus Maximus Augustus. Una enciclopedia internazionale sulla figura, il mito, la critica e la funzione dell'imperatore dell' “editto" di Milano, 6 vols., Bologna - Rome 2013, vol.2, 425-439.

55 See J.W. Drijvers, "Marutha of Maïpherqat on Helena Augusta, Jerusalem and the Council of Nicaea”, Studia Patristica 34 (2001), 51-64. 
fame did not fail to stir up trouble, furtively using gold to win the imperial ear, so that they could play about with the kings as if they were children. ${ }^{56}$

Even before the Muslims started accusing Constantine of having ushered in the practice of imperial interference on faith matters, Christians of all confessions felt the need to accommodate the figure of the convener of the council of Nicaea, especially in light of what the fifth-century councils had brought about. Church councils and Church-State relations were therefore sensitive issues for all Eastern Christians, but much more so for the Melkites, whose very denomination encapsulated this contentious point. It is indeed telling that, before the diffusion of the term 'Melkites,' the Chalcedonians were labelled the 'synodites' in Syrian Orthodox sources, with an implicit reference to their endorsement of the council of Chalcedon. Just as it happened with the accusation of corruption of the Scriptures, this polemical weapon was soon taken up by the Muslims, who, in their attack against the Ahl al-Kitāb (People of the Book) left no internal disagreement unexploited, be it between Jews and Christians or among the different Christian confessions. And Constantine was inevitably caught in the middle. But Islamic sources reveal that Christians and Muslims were not the only ones who fashioned portraits of Constantine based on their own agenda.

The above-mentioned Muslim theologian 'Abd al-Jabbar offers his readers a fourpage account of Constantine's life and deeds that contains rather peculiar information. Samuel Stern has proposed a detailed analysis of this material and has convincingly argued that it comes from an anti-hagiographical tradition on Constantine originated in the pagan, Sabian, milieu of Harran. ${ }^{57}$ The city of Harran plays a prominent role indeed in 'Abd al-Jabbar's narrative: according to it, Helena came from Harran and Constantine carried out there a most fierce persecution of the pagans, which is described at length. Furthermore, two specific customs of the Harranian Sabians appear in the story - namely their strong aversion to leprosy and their prohibition of eating beans - and they are singled out as a specific target of Constantine's persecution. Stern has spotted traces of this very same pagan tradition in three more Muslim texts: ${ }^{58}$

- Al-Mas'udi's historical compendium The Book of Admonition and Revision (c. 956)

- Al-Iskaf's treatise On the Prudent Conduct of Government (late tenth-early eleventh century)

- Miskawayh's history entitled Experiences of the Nations (late tenth-early eleventh century)

56 Translation by S.P. Brock, see S.P. Brock, "North Mesopotamia in the Late Seventh Century: Book XV of John bar Penkāyē's Rĩ̌s Mellē”, Jerusalem Studies in Arabic and Islam 9 (1987), 51-75, esp. 59; repr. in S.P. Brock, Studies in Syriac Christianity, Hampshire - Brookfield VT 1992, II.

57 Stern (cf. fn. 48) 159-164.

58 Stern (cf. fn. 48) 164-176. 
Al-Mas'udi explicitly states that according to pagan (namely Sabian) versions of the story, Constantine had adopted the Christian religion not because of any miraculous healing but because leprosy was a disease that the pagans, contrary to the Christians, would not tolerate in a king. Most remarkably, Al-Iskaf and Miskawayh both report a variant version that includes a trip of Constantine's to Jerusalem and a dispute between Jews and Christians. The Romans wanted to depose Constantine because of his leprosy, but

Constantine said to the Romans: 'Give me a delay so that I can visit Jerusalem; when I come back, I shall resign my rule over you.' They agreed and he went to Jerusalem. He asked the Jews and the Christians to hold a disputation; choosing Christianity he and his followers adopted that religion. He then returned to the land of the Romans, bringing with him monks, priests, and bishops, and invited the Romans to become Christians. The greater part accepted his call, and with their help they fought those who refused. He overcame them, burnt and destroyed their books and their philosophy, built churches and converted the people to Christianity by the sword. ${ }^{59}$

'Abd al-Jabbar, Al-Iskaf and Miskawayh wrote approximately half a century after Agapius, but Al-Mas'udi was Agapius' contemporary and his Book of Admonition and Revision was completed shortly after the latter's chronicle. Stern has provided compelling evidence that all the negative narratives on Constantine reported by these four authors come from a manifold, possibly oral, tradition that was already circulating at, or even before, Agapius' time. By preserving these fragments of pagan anti-Constantinian propaganda, the Muslim sources provide the last piece of the puzzle, enabling us to sketch the context and the issues that urged Agapius (or his source) to fabricate this brand-new episode of the Constantinian saga.

\section{Reshaping Constantine between Byzantium and Islam}

Constantine was the Christian ruler par excellence, the prototype of the Christian king crystallised in the Eusebian paradigm. In the tenth century the symbolic capital provided by his figure was being intensively exploited by the legitimising propaganda of the Macedonian dynasty, a dynasty that was gradually bringing northern Syria under Byzantine control again. But in the East, Constantine was also a controversial figure for being the first convener of a church council. Church councils were seen by Muslims as the means by which Roman emperors had perverted the true Christian faith, and they were a thorn in the flesh for non-Chalcedonian Christians as well. On top of that, ancient pagan accounts that presented a very hostile picture of Con-

59 Stern (cf. fn. 48) 170 -171. Al-Iskaf's and Miskawayh's texts are very close. Stern translates Al-Iskafs' text and indicates additions found in Miskawayh's in the footnotes. 
stantine were still circulating and they were being taken up and retold by the Muslims. Agapius' narrative is a perfect example of the impact on historiography of what John Wansbrough has called the 'Sectarian Milieu.' ${ }^{60}$ In a context in which all other Christian communities had given up on the idea that a Christian empire was needed at all and even pointed out the potential dangers of having a Christian king, Melkites had to defend the figure of Constantine, and therefore of the Christian king toutcourt, from the crossfire of non-Chalcedonians, Muslims, and even pagans like the Sabians of Harran, in order to legitimise the fact that they shared the same faith as the Byzantine emperors. As Agapius tells us, it was not only that Constantine did not pervert the faith but, just like the pious biblical king Josiah, he should be credited with the recovery of the true Word of God, which had been forsaken by the Jews and consequently misinterpreted by the Syriac-speaking Christians. And the original Word of God is now preserved only in Greek, the language of the only legitimate Christian kingdom.

Although Constantine's trip to Jerusalem and his rediscovery of the Septuagint are not recalled in the account of Constantine's reign contained in the second half of the chronicle, the two parts are consistent with each other and they work together to conjure up the apologetic image of Constantine set out above. ${ }^{61}$ In narrating his reign Agapius follows loosely the Greek ecclesiastical histories (notably Socrates of Constantinople and Theodoret of Cyrrus). He begins by immediately presenting Constantine as the first Roman king converted and baptised, then he mentions the foundation of Constantinople and the war against Maxentius, with the episode of the Visio Crucis and the related dream that granted him victory. What leads to his conversion, though, is the healing baptism performed by the bishop of Rome (whom, remarkably, Agapius calls Eusebius instead of Sylvester ${ }^{62}$ ), which is then followed by the dispute between the bishops and the Jews. After his conversion, Agapius reports his intense activity of church building and restoration, his laws in favour of the Christians and his engagement in the forced conversion of pagans and Jews. Helen's pilgrimage to Jerusalem is dealt with very briefly, and with just a swift mention of her recovery of the relics of the Cross. Agapius probably sacrificed Helena's legend because some fundamental items of its plot already appear in the 'Septuagint-Tampering-Constantine' excursus as well as in the Syriac story of Protonike's discovery of the Cross, for which Agapius makes room under the reign of Claudius. Her endeavour, though, is recalled later in association with Shahrbaraz's restitution of the relic to Heraclius. ${ }^{63}$ The account of the Council of Nicaea starts with the text of the letter

60 J.E. Wansbrough, The Sectarian Milieu: Content and Composition of Islamic Salvation History, Oxford 1979.

61 Vasiliev (cf. fn. 29) 539-564.

62 This detail betrays Agapius' familiarity with the Judas-Ciriacus Legend and with the Syriac Julian Romance, see Conterno (cf. fn. 54) 436 and Canella (cf. fn. 34) 81-83.

63 A.A. Vasiliev, Kitab al-'unvan. Histoire universelle écrite par Agapius (Mahboub) de Menbidj (PO 8.3), Paris 1912, 467-468. 
with which Constantine convened the synod. The image of the emperor is that of an organiser who took care of the practical aspects and looked after the council fathers, attended the council without intervening on any of the doctrinal matters, and used his authority only to enforce the decisions taken by the bishops. Socrates' episode of the bishops' mutual accusations that Constantine refused to heed ${ }^{64}$ is also present, but in Agapius' version, instead of encouraging them to forgive each other Constantine says: "If I were to find one of the priests under suspicion or put to the test I would cover him with my robe," a line that signifies a willingness to be the protector of the clergy while not meddling and remaining totally impartial. ${ }^{65}$ Even in the further episodes involving Arius and his partisans and their attempt at being reinstated in the Church, the emperor acts just as a mediator whose unique aim appears to be the reconciliation of the parties. It seems, therefore, as though Agapius wanted the two narratives about Constantine to echo and support one other but avoided blatant overlaps.

Significantly, towards the end of Constantine's reign we find one of the numerous chronological recaps with which the chronicle is interspersed, this time in the form of a list of all the kings that ruled from Adam up to Constantine, reported in two different versions according to the authorities of Africanus and John Chrysostom. ${ }^{66}$ This clearly indicates that Constantine's reign is perceived by Agapius as a watershed moment in the succession of kingship on earth. By inserting the flash-forward narrative on his rediscovery of the 'True Torah' at the time of Abraham, Agapius creates a circle that connects the first Christian king and his time to other positive kingly figures of the past and the relative pivotal historical moments: the biblical patriarchs, Alexander the Great, Ptolemy II, Josiah. Likewise, through the mention of Helena's recovery of the Cross, Constantine is later evoked as an implicit positive parallel to Heraclius, the last Christian king whose regnal years Agapius uses as chronological reference before adopting the Islamic (Hijra) reckoning and caliphal regnal years.

Whether Agapius composed the 'Septuagint-Tampering-Constantine' excursus himself, copied and pasted it from one of his sources, or extracted it and remoulded it at will cannot yet be ascertained, but the reasons why he either fabricated or decided to include this narrative in his chronicle become apparent if we read it against the backdrop of the problematic reception of the figure of Constantine in the Christian and Islamic Near East. The piece happens to fit perfectly the agenda of the tenthcentury Melkite community of Northern Syria, and it gives Agapius the chance to uphold the principle of Christian kingship over and against both non-Melkite Christians

64 Socr., hist. eccl. 1.8.

65 A similar line is ascribed to Constantine also in Michael the Syrian, who probably depends on the same source, see J.-B. Chabot, Chronique de Michel le Syrien, patriarche jacobite d'Antioche (11661199), 4 vols., Paris 1899-1924, I, 245; Conterno (cf. fn. 54) 430-431.

66 Vasiliev (cf. fn. 29) 553-562. 
and Muslims ${ }^{67}$ and to reaffirm the importance of Constantine the Great as one of the linchpins of the chronological architecture of human history designed by God's Providence.

As a last question, it is worth asking ourselves why whoever composed the 'Septuagint-Tampering-Constantine' story did not just rework the existing hagiographical material on Constantine for his own purposes but invented a totally new chapter of the Constantinian saga. Of course, any answer to this question will remain speculative, but one can assume that the author wanted, or needed, to provide new, fresh arguments, based on 'historically grounded evidence,' precisely to counter more effectively the attacks of the Muslims, who were browsing both Christian and nonChristian traditions to build their own polemical arguments. And he brilliantly found a way to kill two birds with one stone, turning the tables on the Jews and the Syriac-speaking Christians through the accusation of tahriff, while at the same time clearing Constantine of any blame. Constantine's trip to Jerusalem was most likely introduced to rectify the Harranian defamatory accounts, which, as we have seen, represent the only tradition where a trip of Constantine's to Jerusalem is to be found, and which in turn had probably borrowed the detail from the Helena legends. The new story, however, should not have sounded totally unfamiliar either. An entirely new story would not have been credible, whereas something that sounded familiar could easily be bought as an authentic piece of truth. The new composition, therefore, had to be skilfully placed within the already existing historiographical and hagiographical tradition, in order to receive authentication and authority from it very much like the Arch of Constantine in Rome.

67 On the Muslim readership of Agapius' chronicle see Conterno (cf. fn. 23) 165-166. 
